\title{
Fiction as prosthesis: Reading the contemporary African queer short story
}

\section{Wesley Paul Macheso}

\section{Fiction as prosthesis: Reading the contemporary African queer short story}

In this article, I read contemporary African queer fiction as a tool employed by writers to represent and rehumanise queer identities in Sub-Saharan African societies. In these societies, heteropatriarchal authorities strive to disable queer agency by dehumanising queer subjects. I argue that African queer identities, desires, and experiences are controlled and restricted under the heterosexual gaze, which strives to ensure that human sexuality benefits patriarchy, promoting heterosexual desire as 'natural' and authentically African and pathologising homosexuality. African writers then employ fiction as a means of rehumanising queer subjects in these disabling heteronormative societies to grant voice and agency to identities that have been multifariously subjugated and/or deliberately erased, and fiction acts as a type of prosthesis, a term I borrow from disability studies. Rewriting such lives in fiction does not only afford discursive spaces to queer identities, but also reconstructs the queer person as a human subject worth the dignity that they are often denied. In the article, I analyse a selection of six short stories from the collections Queer Africa 2: New Stories and Fairytales for Lost Children to demonstrate how these stories function as prosthesis for queer people in disabling societies. Keywords: queer, African fiction, short stories, prosthesis, heterosexual gaze, agency.

\section{Introduction}

In this article, I focus on the role of fiction in rehumanising queer people and reclaiming space for queerness in Sub-Saharan African countries where homosexuality is overtly criminalised by law and/or discriminated against by political figures, cultures, and religions. I analyse a selection of six queer short stories collected in two anthologies: Queer Africa 2: New Stories (2017) (henceforth referred to as Queer Africa 2), edited by Makhosazana Xaba and Karen Martin, and Fairytales for Lost Children (2013) (henceforth referred to as Fairytales) written by Diriye Osman. ${ }^{1}$ What brings the two anthologies in conversation with each other is their thematic threads that revolve around questions of belonging, place, home, and the multiple ways in which queer agency can be cultivated in situations where characters are vulnerable to violence or discrimination. In my reading of the stories, I argue that the writers employ fiction as a tool for rehumanising queer subjects in heteronormative African societies by granting voice and agency to identities that have been subjugated in multiple ways by hetero-patriarchal forces. In most African societies, queer lives are dehumanised (Matebeni, Munro and Reddy 2), and rewriting such lives in fiction does not only afford discursive spaces to queerness but also reconstructs the queer person as a human subject worth the dignity that they are often denied in these societies. In the discussion I employ the theory of "prosthesis", mainly used in disability studies, to demonstrate how fiction becomes an enabling tool in countering the disabling frameworks of queer lives in Sub-Saharan Africa.

The six stories that I discuss here include Yvonne Fly Onakeme Etaghene's "Iyawo", which is a story of two Nigerian lesbian lovers who are ostracised by homophobic regimes in their home country and seek exile elsewhere. I also analyse Juliet Kushaba's "This Tomorrow was Christmas" where the lesbian protagonist, Siima, marries her lover, Nyonyozi, despite her family and community's disapproval of the union. H. W. Mukami's "Pub 360" explores the experience of lesbian women in public spaces in Kenya where homosexuality is illegal. Amatesiro Dore's "The Day he Came" explores a Christian protagonist who struggles with the shackles of patriarchy, masculinity, and religion in his quest to come out as gay. The discussion will conclude with a brief analysis of Diriye

Wesley Paul Macheso is a PhD student in the Department of English, Faculty of Arts and Social Sciences at Stellenbosch University, Stellenbosch, South Africa. His research interests include queer African literature, film, and theory. He also teaches English at the University of Malawi.

E-mail:wmacheso@cc.ac.mw

(D) https://orcid.org/0000-0002-4841-8399

D0l: https://doi.org/10.17159/tl.v58i2.8633

DATES:

Submitted: 14 June 2020; Accepted: 3 March 2021; Published: 16 August 2021 
Osman's "Shoga" and "Tell the Sun not to Shine" which represent experiences of living as an African, Muslim, and gay man in an extremely repressive Somali community.

The analysis is informed by the fact that, despite increasing scholarship on African queer literature, the short story as a genre has not been given enough critical attention as compared to the novel, for example. This is the case even though the short story is a genre that is widely adopted by writers on the continent. Apart from its focus on genre, in this article I advance a theoretical approach that utilises the synergies between disability studies, African masculinities, and feminist thinking in analysing representations of queer identities in African fiction. In this endeavour, I will mainly build on Laura Mulvey's concept of "the male gaze" and David Mitchell and Sharon Snyder's "prosthesis" in analysing the ways in which African writers engage with queerness in contemporary short stories.

Scholars such as Lindsey Green-Simms, Taiwo Osinubi, and Brenna Munro have described African queer writing in the twenty-first century as an emergent genre. By this, they mean that the novelty of such works also evokes notions of "emergency" in that writers have suddenly felt the need to address topics that have been ignored for a long time in African literary history (Munro 188). Munro further argues that "the short story in particular lends itself to trying out ideas" (189). She quotes Catherine Jonet who contends that "for some authors, the short story is the place to openly confront difficult subjects that powerfully affect marginalised groups within a culture" (qtd in Munro 189). For Munro, it is "the as yet to be nature of queer African lives [that] suits the temporalities of the short story" (189). This conception casts the queer African short story as an experimental genre yet to gain full traction.

I agree with the observations by Munro and Jonet in arguing that the short stories that represent queer narratives emerging out of Africa are forms of activism challenging the vulnerability that haunts queer people on the continent and beyond. My analysis further posits that the representation of queer identities in these short stories has now moved past the state of being "emergent" to becoming an established sub-genre that addresses the vulnerability, agency, and activism of marginalised groups within African literature. In its challenge to normative ideologies and institutions, queer African writing has become oppositional in its transformative agenda, as was the early African writing against colonial domination in the 1960s, which include novels like Stanlake Samkange's On Trial for My Country (1967) and James Ngugi's Weep Not, Child (1964), for example. These queer representations are, in essence, deconstructive tools used against the tyranny of heteronormative structures, creating a canonical space for queer subjects in African literature.

These short stories become tools for queer activism in that "they offer vital counter-narratives to widespread homophobia" (Andrews 3) and afford their authors "the opportunity for voicing realities which are often suppressed" (2). As a genre for activism, the short story has varying qualities that make it more effective than, say, the novel. Sally Ann Murray observes that, as a genre, the short story is in itself queer by its unconventionality in form and accessibility as compared to the novel or other forms of writing (80). She argues that "the adaptability of the short story as an outsider configuration has served it well, and seen it foray into service for multiple imaginative engagements with marginality" (Murray 80). The short story as an unconventional or an outsider genre mostly eludes multiple forms of censorship by finding easy ways to publication and distribution through different channels, such as personal blogs and e-magazines, that operate outside the capitalistic confines of traditional publishing. Nevertheless, the biggest challenge in queer activism that the short story faces in most parts of Sub-Saharan Africa is perhaps the economic and linguistic barriers to access faced by the majority of underprivileged and rural populations.

Despite such challenges to access, these stories have the potential to serve as "marginal archives" which "preserve materials excluded from the mainstream" (Hamilton, Harris and Reid ll). As an archive for the existence of gay lives, fiction becomes prosthesis in that it aids in documenting the histories of sexual minorities, thus curating space for them in mainstream discourses on gender and sexuality in Africa, as well as shaping future perceptions of sexual minorities on the continent. As Graeme Reid reiterates, "the way in which lesbians and gay men have been perceived is reflected in the way in which lives and histories have been constructed and documented within the archival holdings of public institutions" (194). As public archives, the short stories under discussion could be essential in reconstructing the often negative image of gay people prevalent in homophobic African societies.

Writing queer lives in African socio-political contexts can be extremely significant in changing social attitudes and increasing visibility for queer issues. Although in some Sub-Saharan African countries (such as the Ivory Coast, Mali, Chad, the Democratic Republic of the Congo, Gabon, Rwanda, and others) same-sex intimacy 
has never been overtly criminalised, thirty-four African countries have outlawed same-sex sexual acts or relationships (Hawley, "In Transition: Self-expression in Recent African LGBTIQ Narratives" 121). For those countries that are silent on the rights of sexual minorities, the question that arises is: to what extent can such silences on the rights of sexual minorities amount to a different form of marginalisation that is just as detrimental as the overt criminalisation of homoerotic desire? Writing about queerness goes a long way in breaking the silence on this topic and has the potential of granting agency to queer people as a vulnerable group deliberately pushed to the margins of these societies.

Ayodele Sogunro observes that "[the] invisibility and consequent perception of non-existence [of queer people in most parts of Sub-Saharan Africa] has a serious repercussion" in that "it can be propelled as evidence of socio-cultural disapproval of LGBTI persons and then used to justify further violations against sexual minorities" (636). He further argues that the dehumanisation of queer identities also places the African queer writer in a precarious position. ${ }^{2}$ This vulnerability of the writer is evident in countries like Nigeria and Uganda where the law even prohibits advocating for queer rights in any form (Sogunro 633). In such environments, life writing by queer subjects, for example, becomes a life-threatening endeavour since the identification of the author with the protagonist in the work may put such authors at risk of persecution, arrest, and even violence or death. Unlike in South Africa, where constitutional provisions have tried to open avenues for the expression of queer lived experiences, alternative genres of writing, like fiction, become convenient in societies where it is illegal to identify as queer. It should also be mentioned that, despite South Africa's "constitutional commitment granting rights to sexual minorities, people with nonconforming gender identities still face several challenges that threaten their basic rights to equality in the country" (Macheso 1). This is where writers as activists (whether the activism is intended or unconscious) are needed to employ writing fiction as a tool for the expression of non-normative and vilified identities. I thus explore these short stories as forms of visibilising queer African experiences through a genre that offers creative possibilities in its propensity to experimentation. I regard this work as activism since it challenges the erasure of queer lives from African societies.

\section{The heterosexual gaze and prosthesis in African queer fiction}

As highlighted earlier, my approach to reading the significance of these short stories relies on ideas from disability studies, feminist theory, and concepts from African masculinities studies. I have employed this intersectional theoretical approach in order to be able to identify the roots of queer marginalisation, which is perpetuated by patriarchal systems in African cultures, and to demonstrate ways in which the writing of fiction has come to serve as a tool for disrupting such normative dictates so as to grant agency and voice to the marginalised. On the one hand, patriarchy and its set of idealised traditional gender roles marginalises queerness under what I call "the heterosexual gaze", a form of scrutiny and surveillance from state, culture, religion, and social groups which controls sexuality, creating a disabling environment for queer subjects in many societies, including most parts of Sub-Saharan Africa. On the other hand, writers employ the writing of fiction as prosthesis, allowing them to bring to the fore identities and sexual practises that these societies try to suppress. In this way, fiction becomes an agentic tool for queer activism in Africa's heteronormative societies.

In her landmark work Visual and Other Pleasures (1989), Laura Mulvey discusses how women come to occupy subordinate positions in patriarchal societies and the means through which patriarchy gains and maintains such control over time. She notices that "woman [...] stands in patriarchal culture as the male other, bound by a symbolic order in which man can live out his fantasies and obsessions through linguistic command by imposing them on the silent image of woman still tied to her place as bearer, not maker, of meaning" (Mulvey 15). Mulvey ties the subordination and objectification of women to what she calls "the determining male gaze [which] projects its fantasy onto the female figure, which is styled accordingly" (19). Although her coinage of "the male gaze" specifically refers to the roles of women in visual media and particularly cinema, Mulvey's ideas broadly speak to the position of power held by heterosexual men over women in patriarchal societies. I conceive the "gaze" as that position of privilege from which women's bodies and their sexualities are controlled under the watch of patriarchy. I adopt this concept to speak about the way sexual and gender minorities are viewed and framed within heteropatriarchal societies. I regard the "gaze" as a reading strategy employed by those in power to subject bodies and lived sexual realities under the control of heteronormativity.

Mulvey's concept of the male gaze is essential, not only in understanding the relationship between men and women in society, but also in comprehending the contentious nature of all relationships that centre on gender. 
The gaze that she evokes is not only male, but also heteropatriarchal, and it plays a crucial role in controlling and commodifying sexuality in heteronormative societies, consequently oppressing homosexuality as it exists outside the parameters of normative gender roles. As Judith Butler argues, "heterosexuality is cultivated through prohibitions, where these prohibitions take as one of their objects homosexual attachments, thereby forcing the loss of those attachments" (25). In this regard, the oppression of homosexual subjects under the male gaze is achieved through manifestations of heterosexual hegemonic masculinities that ensure the dominance of heterosexual men over their homosexual counterparts (Connell 78).

Through the mechanisms of patriarchal control in heteronormative societies, the gaze that controls sexuality is broadened from not merely being male but also heterosexual. I define the heterosexual gaze as that position of privilege and authority occupied by both heterosexual men and women who exercise power over gender and enforce sexual normativity in these societies. As Catherine Hakim relates, "patriarchy has proved a useful concept in feminist theory, identifying how men, and the social institutions created and controlled by men, have actively subordinated women [...]" (2), and by extension, homosexual men. Heterosexual women have also become actively interpellated in the social structures and practices of patriarchy in that they have come to play active roles in controlling what are regarded as dissident sexual desires in the form of same-sex sexualities.

The short stories I analyse here reveal that the control that heteropatriarchy exercises on people's sexuality tends to be capitalistic in that there is a dire need in patriarchy to commodify sexuality for its own benefit. To borrow from Nicole Constable, "in Marxist terms, commodification refers to the process of assigning market value to goods or services that previously existed outside of the market" (50). The idea of assigning market value entails an anticipation of profit from whatever form of relationship exists between the parties involved therein. For purposes of this analysis, I employ the concept commodification of sexuality to refer to the anticipated value, profit, or gain that patriarchy attaches to social practices and interactions. There is an underlying assumption that human (sexual) behaviour must benefit the needs of heteropatriarchal authority and therefore must be put under a constant gaze in order to, in Foucauldian terms, 'discipline and punish' nonconformity (Foucault 1977). Such anticipated gains may range from sexual reproduction and bride prices received for heterosexual marriage arrangements, to elusive conceptions of family dignity, communal coherence, cultural preservation, and achievements of high moral standards that are seen to emanate from conformity to heteronormativity.

In my reading of these short stories, I regard creative fiction as a tool that has deliberately been taken up by some African writers in bringing to light subjects that cannot be discussed freely in Sub-Saharan African countries that criminalise same-sex sexuality and gender nonconformity. In doing so, I rethink the concept of prosthesis from its application in disability studies to how it may be reconceived in other instances within narratives of lives of 'marked identities'. To quote Mitchell and Snyder, "under gender, gay men and women constitute 'marked' identities while their heterosexual counterparts are considered normal" (ix). In their adaptation of David Wills' concept of "prosthesis" to disability studies, Mitchell and Snyder examine how the disabled body is represented in literature and argue that "literary works often leave the disabled body as a troubled and troubling position within culture" (8). They coined the term "narrative prosthesis" to unveil the ways in which representations of disability in creative art have failed to challenge the marginalisation faced by disabled people and disability in general.

While Mitchell and Snyder critique the representation of disability as narrative prosthesis in that it harbours the risk of reproducing marginality through metaphorical representations that entail lack and deficiency in people with disabilities, I do not regard the presence of queer characters in these short stories as narrative prosthesis. Rather, I consider the writing of fiction itself as prosthesis in disabling environments where it may be too risky to employ other forms of representation. I conceive most nation-states in Sub-Saharan Africa as disabling environments for people with queer identities and same-sex sexualities due to punitive laws, culture, and religion that work together to incapacitate queer agents. As such, literary artists seek prosthetic tools to represent and rehumanise queer identities in these societies where heteropatriarchal authorities have dehumanised and marginalised queer people.

Fiction, through its imaginative capacity, proves to be one of the most potent tools in this endeavour, and as the short stories discussed in this article reveal, creative fiction as prosthesis has worked to transcend normative boundaries on what is and what is not allowed in public discourses in these disabling socio-political environments, and has enabled the presence of queer people in spaces where they previously were excluded and made invisible. The potency of the imaginative capacity of fiction in challenging heteronormativity firstly lies in its imi- 
tation and representation of real-life experiences in ways that go beyond mere mimesis to suggesting possibilities for alternative worldviews and modes of expressing gender and sexuality through creative reimagining of current social systems. As prosthesis, fiction does not only depict queer lives as they are, but also represents them as they could be.

Apart from humanising queer people in social relations, fictional representation as prosthesis also functions as a tool for expressing the quotidian challenges faced by queer subjects and establishing their legitimate claims to space as equal members of the human society. In most of the stories under discussion, queer characters have been represented as complex characters with everyday concerns and aspirations, in addition to facing marginalisation due to their same-sex sexualities. In this way, literary fiction becomes a means of countering the invisibility of queer people in heteronormative African contexts. Queer identities, same-sex sexualities, and non-normative gender expression have mostly been restricted to private spaces in most parts of Sub-Saharan Africa, and one way of countering such marginalisation is by creating space for such experiences in the public domain for the recognition and acceptance of difference. As alluded to earlier, public literary works are accessible to a broad audience and offer the possibility of recognition for queer people in repressive societies.

\section{African lesbians and the (im)possibilities of love}

As discussed above, the heterosexual gaze is capitalistic in nature in that it commodifies sexual relations and defines normativity in terms of that which benefits patriarchal male figures. In order to maintain this ideology, societies in Sub-Saharan Africa exercise control over sexual minorities to the extent that queer identities are vilified as abominable and queer subjects are relegated to the margins as the undesirable others. In countries like Nigeria, Uganda, and Kenya, where laws prohibit lesbian desire, lesbian women often struggle with feelings of alienation, not only from their countries, but also from their sexual identities that might be seen to estrange them from their immediate environment. Dobrota Pucherova notices that the emergence of $21^{\text {st }}$ century African lesbian fiction has highlighted "the ways women are victimised through patriarchal control over their sexuality" (107). African women, especially lesbians, "have been excluded from equal citizenship, their desires and needs sacrificed for the survival of "tradition"' (110). Lesbian women on the continent are considered outcasts since hegemonic African masculinities define a "real" African woman as one who is available to satisfy the sexual appetites of heterosexual men (Ratele 124). As such, contemporary African lesbian fiction "seeks to not only challenge homophobia in Africa, but to redefine the idea of African femininity, the African family, and African society away from heteronormativity" (Pucherova 110).

In the stories that depict lesbian desire in both Queer Africa 2 and Fairytales, women who are in love with other women are represented as subject to the heterosexual gaze in multiple ways. The stories reveal that there is a need in men in these texts to control female sexuality through heterosexual marriage in which women's bodies should serve to satisfy male desire and be vessels for reproduction. In a conversation with her lover, Ronke, the Nigerian lesbian protagonist in Etaghene's "Iyawo" reminds her that "[t]here are men in the other room who expect us to bear them babies, bare our bodies to them, keep the house, shut up and laugh at their jokes [...] Obligation is slavery" (37). She continues to argue that "I don't believe in marriage-the institution, the obligation, the compulsory baby-making, the bullshit" (Etaghene 38). In such statements, the narrator unpacks the ways in which heteropatriarchy strives to exercise control over female sexuality by repudiating lesbianism through the promotion of heterosexual marriage, which benefits patriarchy by reproducing its structure of power differentials between men and women.

The yoke of heterosexual marriage also proves to be a burden for the lesbian narrator, Siima, in Kushaba's "This Tomorrow was Christmas" where her family refuses to recognise her lover, Nyonyozi, as a possible suitor because she is a woman. Set in Uganda, Kushaba begins the story by describing the intimidating figure of a pastor who condemns Siima because she "refused to marry a man from one of the most affluent families in the village, [and she] denied [her] widowed mother the numerous cows the suitor's family was willing to give her for [her] bride wealth" (12). Here, Siima's choice in refusing to marry a wealthy man becomes a condemnable gesture and a perceived loss to heteropatriarchy. Both the pastor and her family operate in service of the patriarchal authority as Siima is scrutinised under the heterosexual gaze to enforce normativity by making sure that she lives according to social expectations. It is such enforcement of heterosexual norms that deny lesbians their agency and control over their bodies and sexualities and threaten their basic survival in such societies. As evidenced here, the society tries to commodify Siima's sexuality so that it profits the demands of patriarchy through bride wealth and the 
possibility of a heterosexual family setup. As such, her same-sex sexuality is condemned as it is a direct challenge to patriarchal control.

Kushaba employs fiction as prosthesis to bring to light such challenges faced by lesbians in the face of heteronormativity. Normally, these forms of oppression are not discussed in public, fuelled by public discourses that lesbians do not exist in African societies, and thus taking away their agency. However, the ending of her story demonstrates the possibilities of the agency of queer people in the face of heteropatriarchal constraints. Despite that Nyonyozi is not recognised by the society as a possible suitor, Siima still gathers the courage to tell her mother that "Nyonyozi and I are married [...] We got married two years ago and tomorrow is our anniversary" (Kushaba 178). The story ends with this revelation and the author does not afford the mother a chance for a response.

Kushaba's narrative strategy to give voice to Siima's coming out and deny her mother a possible reprimand aims to portray that the decision and final say on whom one loves and chooses to be with lies with the subject in question. Another interesting feature in the story is that Siima and Nyonyozi are to celebrate the anniversary of their union on Christmas day. Here, the author destabilises the moral egotism in most Christian establishments by casting the importance of the birth of a queer union over the birth of a prominent figure within one of the impediments to queer agency - Christianity. In most African countries, religion (especially Christianity and Islam), coupled with patriarchal traditional cultures, are upheld as guides to morality and are responsible for the policing of gender and sexual variance (Olaoluwa 20-1). Considering this, the marriage of Siima and Nyonyozi on Christmas day becomes one of the story's central challenges to heteronormative authority.

In her story, "Pub 360", Kenyan author H. W. Mukami demonstrates the operation of the heterosexual gaze through her portrayal of a barman who disapproves of sexual desire between two women. The two women, Ashuni and Oluchi, meet in a bar called Pub 360 which is owned by a closeted lesbian woman who also acts as narrator of the story. The two women begin a conversation, and their mutual attraction is obvious. This offends the barman in the pub who "muttered inaudibly under his breath and his brow creased. He looked disturbed" (Mukami 239). The disgust in the barman's attitude is due to his disapproval of lesbian affection in public places in Kenya. As a patriarchal figure, the barman feels that it is his duty and responsibility to enforce his ideal of 'moral correctness' and discipline the two women. When the lovers eventually "locked their arms and held each other" (240), the barman erupts in anger, chases the two women out of the bar, and uses homophobic and sexist epithets.

Firstly, he calls the women "a pair of black whores" (240) since they operate outside the expectations of his male, heterosexual gaze. As Amanda Lock Swarr remarks, lesbians are often persecuted because they "are perceived as both threatening and unavailable by men in their communities" (962). The barman's remark that the two women are performing "free pornography" (Mukami 240) reveals his underlying assumption that same-sex affection or attraction between women ought to be staged for the satisfaction of the heterosexual male gaze. In addition, because the women challenge heteronormativity, the barman regards the women as immoral and wants to create a discourse of shame in order to enforce limits on their agency.

The women in the story challenge heteropatriarchal power as exercised by the barman. Upon noticing the abuse, the narrator steps forward and immediately fires the barman for his actions. She contemplates: "Who had done wrong? Was it so wrong to feel, to be who you are?" (241). She concludes by resolving that "[i]t was time to right a wrong, and I had to start somewhere" (241). Her agency is geared towards the creation of space for queer identities in African heteronormative societies, something that the short stories as prosthetic tools also endeavour to do. It is vital to notice that her pub only becomes a safe space for the lesbian women upon the removal of the barman, which may symbolise the need to dispose of patriarchal practices, structures, and systems in order to create safe spaces for queer individuals in these punitively heteronormative societies. The story demonstrates how such safe spaces reduce the risk of danger and become sites of agency for queer people.

Despite often being denied agency in public spaces, the lesbian characters in these stories exercise relative authority over their sexualities, mostly outside the ambits of the restrictive heterosexual gaze, and make counter-normative choices. As the protagonist in Etaghene's "Iyawo" laments, "[i]f we made this world with our bare hands instead of by the accidental destiny of birth, our love, this love between us women, would be sanctified in public spaces, temples, in the market, on the dirt roads we were raised on" (35). But in the absence of such recognition for same-sex sexuality in her society, she argues that lesbian love can still flourish in private spaces where women can "laugh when it's funny, roll [their] eyes when it's not, fuck [their] best friends in the middle of the night with hard, rough tenderness then go back to fathers, lovers, husbands, brothers" (36, emphasis in original). While such performances of queer desires and identities are still not fully enabling, they can signify agency for 
these lesbian characters and can demystify the concept of queer people as others and dispel ideas of the threat that queer people supposedly pose in these societies. As prosthesis, the stories discussed here work in redefining established ideas of African womanhood, femininity, love, and the African family in their challenge to homophobia in African societies.

\section{Gay bashing and the invisibility of queer men in African 'straight spaces'}

For same-sex sexualities in women, the heterosexual gaze often strives to control women's sexuality through social expectations of compulsory heterosexual marriage and pathologizing same-sex desire; however, with male homosexuality, it is often the masculinity of gay men that is questioned by the heteronormative culture. Most of the short stories that explore the lives of gay characters in the two anthologies reveal that gay bashing is one of the main ways through which gay subjects are dehumanised to deny them space in mainstream culture. ${ }^{3}$ In these stories, gay bashing often starts with verbal abuse before it turns into physical violence. Straight characters taunt their gay counterparts by calling them names that connote aspects of uncleanliness, effeminacy, and abnormality, in order to marginalise them. These practices are normalised in heteronormative societies and the psychological distress of the targeted gay subjects is often ignored. Due to their invisibility in these societies, gay men often suffer in silence and their victimisation is seldom given audience. As such, the short stories under discussion serve as prosthesis by bringing to the fore the impact of such abuses on gay men generally in these disabling social environments. Telling such stories can become enabling as it may open avenues for public discourses on the plight of gay men in homophobic African societies.

Robert Morrel contends that hegemonic masculinity, which is often identified with heterosexual middleclass men, does not only function through the oppression of women, but also through ensuring the subordination and silencing of other masculinities (608). He further argues that, among the defining features of this form of masculinity, are misogyny, compulsory heterosexuality, and homophobia (608). This entails that the masculinities of gay men are considered inferior under hegemonic masculinity, and such conceptions of inferiority justify the victimisation of sexual minorities through social practices like gay bashing.

Kopano Ratele notices that it is very difficult to define and perform hegemonic African masculinity since this form of masculinity is already undermined by power differentials based on racism and capitalism, for example (117). As such, he argues that it is in this way that homophobia and forms of gender-based violence have their "'uses' in Africa as a kind of explanation (or better still, displacement) of the impossibility of attaining and maintaining traditionally hegemonic African masculinity. The 'homosexual' then, is what a real African man is not, and a defining characteristic of the dominant male position is violence" (Ratele 117 , emphasis in original). The violence that heterosexual men perpetrate on sexual minorities can thus be argued to stem from the need to demonstrate the purported power that their hegemonic masculinity affords them. And since hegemonic masculinity is always threatened by the existence of different forms of masculinity that constantly challenge it (Morrel 608), its insecurities lead to both verbal and physical violence against gay men in heteronormative African societies and cultures.

In Dore's "The Day He Came", the protagonist, Larry, struggles with feelings of insecurity about his masculinity as he believes his effeminate traits give him away as gay. Larry grows up in a Christian home where his father is a well-known pastor and his mother a gospel musician. Renaming himself from Peter to Larry (at least among his peers) becomes one of the ways the protagonist rids himself of the pressure of religious expectations from his parents as he relinquishes the Biblical name. In the home, Larry is often compared to his twin brother, Paul, who is celebrated by the father as "the real man". The feeling that he is not masculine enough becomes obsessive, and he does not want anyone to remind him of what he regards as a deficiency. When a friend, Michael, calls him "pretty", Larry challenges him vehemently, telling him that "I object to and take offence at every attempt to abrogate my manhood and circumscribe my sexuality" (Dore 49).

His insecurity borders on the fear that he is not "man enough" as per the requirements of heteronormative African ideals of masculinity. Larry fails to measure up to the standard of how "putative 'real men' should behave as a cultural ideal" (Morrel 608). Due to this fear, he keeps his sexuality secret for most of the story. One of the reasons for staying in the closet is that, since his secondary school days, Michael verbally abuses him for his femininity, and he feels unable to come out as gay. Among other things, Michael calls him "Laura" (Dore 53) instead of Larry as a way of reminding him that he is not man enough.

Larry recounts "[h]ow [he] hated secondary school and felt suicidal because of [Michael's] name-calling, the feminine pronouns he designated for [him] and how he treated [him] like a girl" (53). Larry remembers these 
moments upon realising that his abuser had always been gay despite his constant gay bashing. Michael referring to Larry in feminine terms demonstrates one way that heteropatriarchal culture discriminates against gay men, and also reveals Michael's ambivalent attitude towards his own repressed homosexuality. Michael thinks that by appearing to be anti-gay, his homosexual desire would be concealed, and he would remain invisible to the controlling heterosexual gaze. In this way, he does not only take away agency from Larry, but diminishes his own ability to accept his sexuality.

In "Shoga", Osman's narrator first experiences gay bashing from his immediate family. His grandmother disapproves of his effeminate mannerisms and tells him that "[w]aryaa, if you grow up to be gay, walaahi I will do saar" (Osman, Fairytales 33). The narrator explains that "Saar was a brand of Somali exorcism. Those 'possessed'which was code for the mentally unstable - were put through their paces" (Osman, Fairytales 33). The association of same-sex desire with mental illness runs through most of the stories in Fairytales. The fact that Osman himself is a gay man who was diagnosed with psychosis and institutionalised (Osman, "How Mental Illness Fed My Creativity" n. p.) makes most of these stories read as semi-autobiographical testimonies of living as a queer, Muslim, and African man, something that has similarly been observed by other scholars (see for example Aragon; Lombardi; Binternagel).

Osman's semi-autobiographical narratives in some of the stories in Fairytales demonstrate the role of literary fiction as prosthesis in that, by blending his real-life experiences within fictive imaginaries, he is able to extend such experiences by not only telling what is/was, but also what could be. Writing fiction enables him to use his lived experiences to narrate the plight of other queer people in heteronormative societies by detaching the experience from himself to his characters with whom other gay people can identify. In this way, Osman solicits empathy, not only for himself, but for queer people in general who may be facing similar challenges in different places. Commenting on the history of experimentation in South African autobiographical novels and fictional autobiographies, Gabeba Baderoon notices that the blurring of borders between autobiography and fiction "confront [s] the vulnerability of autobiography to claims of distortion, lying, and misinterpretation, and use[s] the very imprecision, fragility, and blurred edges of self-writing to potent effect to create new forms of subjectivity and political belonging" (898). In the case of Osman, the fact that his stories are published as fiction while containing autobiographical elements leaves them open to interpretation beyond the analytical limits that come with the identification of the author's life with the text in autobiographical studies.

The verbal abuse identified in these stories does not only affect gay men, but also lesbian women, who in Somali society are called "Khaniis" (Osman, Fairytales 41). One of the most detrimental effects of gay bashing is that it leads to the invisibility of queer people from what are regarded as 'straight spaces' in heteronormative societies. The short stories demonstrate that, for fear of abuse, queer people either become completely silenced or create alternative spaces where they can perform their queer identities. In the story "Tell the Sun not to Shine", Osman details the challenges of coming out in patriarchal and heteronormative Muslim communities. The story's narrator is in love with Labaan, an Imam at his mosque, but they keep their relationship secret for fear of scorn from their community. He recalls that, after a night of intimacy, the two lovers "would go about [their] day wondering if the previous night even happened" since Labaan "was trying to dodge a life of complications" (Osman, Fairytales 10).

The narrator recognises that his relationship with Labaan is complicated due to its secrecy and what coming out would entail. This becomes a constant cause of psychological distress for him throughout the story. To make matters worse, the narrator is later disowned by his parents upon coming out and Labaan was married to a woman all along. The complications in this relationship are reflected in the title of the story as it suggests that the drive to make queer people invisible as a strategy to somehow expel their same-sex sexualities is as impractical and implausible as telling the sun not to shine. As prosthesis, this story is crucial in that it enables Osman to tread dangerous terrain as, through fiction, he is able to talk about same-sex sexuality within restrictive Muslim-majority communities which have been identified as "being the least accepting of gays in the world" (Hawley, "Desiring Africans: An Introduction" 3). In this way, fiction becomes an enabling endeavour.

Most of the stories in Fairytales focus on the experiences of the protagonists as children and/or adolescents growing up in heteronormative societies where queer realities are absent in broader sociocultural discourses. Bernie Lombardi contends that "[i]n twenty-first century African writing, the proliferation of queer childhood, as a common trope, increasingly demands re-imaginations of belonging beyond the nation without rejecting African geography as its locus" (688). He goes further to argue that such narratives are efforts by queer African writers to disrupt African ontologies as queer childhoods demonstrate the continued existence of queer individuals, even 
in the future (688). Adding to Lombardi's observation, portrayals of queer childhoods also open possibilities for queer futures by disrupting the workings of the heterosexual gaze by proving false the assumption that all humans are heterosexually oriented from childhood all the way through adulthood. Additionally, such depictions point to the roots of homophobia in African societies by exposing the invisibilising of queer people in social discourses, including school curriculums, which lead to prejudice and gay bashing. To evoke Eve Kosofsky Sedgwick, such misconceptions are often products of psychological discourses that present queer adulthoods as cases of psychopathology resulting from a failure to correct "proto-gay" childhoods (22). As prosthesis, the short stories discussed here attempt to challenge such misunderstandings of queer people by asserting belonging for African queer people and writing same-sex sexualities in the African imaginary.

\section{Conclusion}

In this article, I have analysed a selection of African queer short stories from two collections: Queer Africa 2: New Stories and Fairytales for Lost Children. My discussion has established that contemporary African writers capitalise on the potency of literary fiction in creating narratives that act as prosthesis to bring to light the realities of queer people in punitively heteronormative Sub-Saharan African countries where same-sex intimacy is outlawed. The short stories demonstrate that same-sex sexuality is abhorred in most parts of Sub-Saharan Africa mainly because queer intimacy challenges the controlling gaze of heteronormativity and patriarchy. As such, patriarchal systems and structures inhibit the agency of lesbian women and gay men, relegating them to the margins of society where they become invisible. Based on this invisibility, heteropatriarchal authority erroneously sees same-sex sexuality as un-African in justifying the victimisation of queer people. In consequence, there is a growing trend among African writers to create spaces that are freer from harm for queer people on the continent. The representations of queer identities in these narratives unearth the multiple challenges that sexual minorities face in Africa while at the same time giving room to possibilities for agency and possible futures of emancipation, as well as soliciting empathy for queer people in Africa.

\section{Notes}

1. Osman's short stories in this collection feature African characters (mostly Somali), most of whom live in exile in Kenya and the United Kingdom. The two stories that I analyse here are set in Kenya where the main characters struggle against the homophobia around them. It should, however, be mentioned that even those characters who search for refuge overseas in some of the short stories still become victims of homophobia, mostly from their immediate families who believe that same-sex sexuality is un-African.

2. In his article, Sogunro uses the term 'African queer writer' to refer to writers who explicitly identify as queer in their gender and sexual orientation. In addition, African writers who engage with queer themes may also be referred to as 'queer writers' by the mere fact that their narratives deviate from the 'norm' in African literature. Such writers can also be at risk of abuse from homophobic publics or structures.

3. Peter M. Nardi and Ralph Bolton define gay bashing as "violence, threats of physical harm, verbal abuse, and other types of aggression directed against individuals because of their sexual orientation" (349).

\section{Works Cited}

Andrews, Grant. "The emergence of black queer characters in three post-apartheid novels." Tydskrif vir Letterkunde vol. 56, no. 2, 2019, pp. 1-9. DOI: https://doi.org/10.17159/2309-9070/tvl.v.56i2.5843.

Aragon, Asuncion. "Breaking/Voicing the Silence: Diriye Osman's Fairytales for Lost Children." Queer Theory in Film e Fiction: African Literature Today 36, edited by John C. Hawley, et al. James Currey, 2018, pp. 123-34.

Baderoon, Gabeba. "“I Compose Myself": Lesbian Muslim Autobiographies and the Craft of Self-Writing in South Africa." Journal of the American Academy of Religion vol. 83, no. 4, 2015, pp. 897-915. DOI: https://doi.org/10.1093/jaarel//fv075.

Binternagel, Jordi G. "The Representation of Queer African Identities in Fairytales for Lost Children by Diriye Osman." MA Thesis. U of the Balearic Islands, 2018.

Burger, Bibi. "Queer Africa 2 (Makhosazana Xaba and Karen Martin).”. Tydskrif vir Letterkunde vol. 55, no. 2, 2018, pp. $172-4$. DOI: https://doi.org/10.17159/2309-9070/tvl.v.55i2.4858.

Butler, Judith. "Melancholy Gender/Refused Identification." Constructing Masculinity, edited by Maurice Berger, Brian Wallis, $\&$ Simon Watson. Routledge, 1995, pp. 21-36.

Connell, Raewyn. Masculinities. $2^{\text {nd }}$ edition. U of California P, 2005.

Constable, Nicole. "The Commodification of Intimacy: Marriage, Sex and Reproductive Labor." Annual Review of Anthropology vol. 38, no. 49-64. 2009, pp. 49-64. DOI: https://doi.org/10.1146/annurev.anthro.37.081407.085133.

Dore, Amatesiro. "The Day He Came." Queer Africa 2: New Stories, edited by Makhosazana Xaba \& Karen Martin. Ma Thoko's, 2017, pp. 47-58.

Etaghene, Yvonne F. O. "Iyawo." Queer Africa 2: New Stories, edited by Makhosazana Xaba \& Karen Martin. Ma Thoko’s, 2017, pp. 33-40.

Foucault, Michel. Discipline and Punish: The Birth of the Prison, translated by Alan Sheridan. Vintage, 1977. 
Green-Simms, Lindsey. "The Emergent Queer: Homosexuality and Nigerian Fiction in the $21^{\text {st }}$ Century." Research in African Literatures vol. 47, no. 2, 2016, pp. 139-61. DOI: http://doi.org/10.2979/reseafrilite.47.2.09.

Hakim, Catherine. "The Sugar in His Tea: Sexuality, Patriarchy and Sexual Politics." Sociologica vol. 3, 2016, pp. 1-28. DOI: https://www.rivisteweb.it/doi/10.2383/85805.

Hamilton, Carolyn, Verne Harris \& Graeme Reid. "Introduction.” Refiguring the Archive, edited by Carolyn Hamilton, et al. Springer, 2002, pp. 7-18

Hawley, John C. "In Transition: Self-expression in Recent African LGBTIQ Narratives." Journal of the African Literature Association vol. 11, no. 1, 2017, pp. 120-34. DOI: https://doi.org/10.1080/21674736.2017.1335951.

"Desiring Africans: An Introduction." Queer Theory in Film \& Fiction: African Literature Today 36, edited by John C. Hawley, et al. James Currey, 2018, pp. 1-6.

Kushaba, Juliet. "This Tomorrow was Christmas.” Queer Africa 2: New Stories, edited by Makhosazana Xaba \& Karen Martin. Ma Thoko's, 2017, pp. 173-8.

Lombardi, Bernie. "'Watering the Imagination': Childhood and the Spaces of African Queerness." College Literature: A Journal of Critical Literary Studies vol. 45, no. 4, 2018, pp. 687-94. DOI: http://doi.org/10.1353/lit.2018.0043.

Macheso, Wesley P. "Vulnerability and the (im)possibilities of becoming: transgenderism in contemporary South African life writing." African Identities, 2020, pp. 1-14. DOI: https://doi.org/10.1080/14725843.2020.1803044.

Matebeni, Zethu, Surya Munro \& Vasu Reddy, eds. Queer in Africa: LGBTVI Identities, Citizenship, and Activism. Routledge, 2018.

Mitchell, David T. \& Sharon L. Snyder. Narrative Prosthesis: Disability and the Dependencies of Discourse. U of Michigan P, 2000.

Morrel, Robert. "Of Boys and Men: Masculinity and Gender in Southern African Studies." Journal of Southern African Studies vol. 24, no. 4, 1998, pp. 605-30. DOI: https://www.tandfonline.com/doi/abs/10.1080/03057079808708593.

Mukami, H. W. "Pub 360." Queer Africa 2: New Stories, edited by Makhosazana Xaba \& Karen Martin. Ma Thoko's, 2017, pp. 237-44.

Mulvey, Laura. Visual and Other Pleasures. Palgrave, 1989.

Munro, Brenna M. "States of Emergence: Writing African Female Same-sex Sexuality." Journal of Lesbian Studies vol. 21, no. 2 , 2016, pp. 186-203. DOI: https://doi.org/10.1080/10894160.2016.1148471.

Murray, Sally-Ann. "Queerying Examples of Contemporary South African Fiction." Journal of Commonwealth Literature vol. 55, no. 1, 2018, pp. 77-95. DOI: https://doi.org/10.1177/0021989418788909.

Nardi, Peter M. \& Ralph Bolton. "Gay-Bashing: Violence and Aggression Against Gay Men and Lesbians." Advances in Psychology vol. 76, 1991, pp. 349-400. DOI: https://doi.org/10.1016/S0166-4115(08)61062-6.

Ngugi, James. Weep Not, Child. Heinemann, 1964.

Olaoluwa, Senayon. "The Human and Non-human: African Sexuality Debate and Symbolisms of Transgression." Queer in Africa: LGBTशI Identities, Citizenship, and Activism, edited by Zethu Matabeni, Surya Munro \& Vasu Reddy. Routledge, 2018, pp. 20-40.

Osinubi, Taiwo A. "Queer Prolepsis and the Sexual Commons: An Introduction." Research in African Literatures vol. 47, no. 2, 2016, pp. vii-xxiii. DOI: http://doi.org/10.2979/reseafrilite.47.2.01.

Osman, Diriye. Fairytales for Lost Children. Team Angelica, 2013. "How Mental Illness Fed My Creativity.” Diriye Osman/The Afrosphere. 18 Aug. 2017, https://www.diriyeosman.com/ post/2017/08/18/how-mental-illness-fed-my-creativity.

Pucherova, Dobrota. "What is African Woman? Transgressive Sexuality in 21 ${ }^{\mathrm{st}}$-Century African Anglophone Lesbian Fiction as a Redefinition of African Feminism." Research in African Literatures vol. 50, no. 2, 2019, pp. 105-22. DOI: http://doi. org/10.2979/reseafrilite.50.2.08.

Ratele, Kopano. "Hegemonic African Masculinities and Men's Heterosexual Lives: Some Uses for Homophobia." African Studies Review vol. 57, 2014, pp. 115-30. DOI: http://doi.org/10.1017/asr.2014.50.

Reid, Graeme. "The History of the Past is the Trust of the Present': Preservation and Excavation in the Gay and Lesbian Archives of South Africa." Refiguring the Archive, edited by Carolyn Hamilton, et al. Springer, 2002, pp. 193-208.

Samkange, Stanlake. On Trial for My Country. Heinemann, 1967.

Sedgwick, Eve K. "How to Bring Your Kids Up Gay.” Social Text, no. 29, 1991, pp. 18-27. DOI: https://doi.org/10.2307/466296.

Sogunro, Ayodele. "Citizenship in the Shadows: Insights on Queer Advocacy in Nigeria." College Literature: A Journal of Critical Literary Studies vol. 45, no. 4, 2018, pp. 632-40. DOI: http://doi.org/10.1353/lit.2018.0037.

Swarr, Amanda L. "Paradoxes of Butchness: Lesbian Masculinities and Sexual Violence in Contemporary South Africa." Signs vol. 37, no. 4, 2012, pp. 961-86. DOI: https://doi.org/10.1086/664476.

Xaba, Makhosazana \& Karen Martin, eds. Queer Africa 2: New Stories. Braamfontein: Ma Thoko's, 2017. 